\title{
VOLATILE COMPOUNDS IN HONEY PRODUCED IN THE CENTRAL VALLEY OF ÑUBLE PROVINCE, CHILE
}

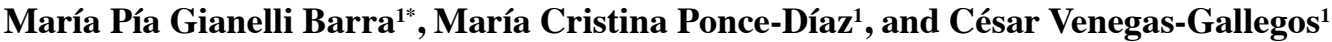

\begin{abstract}
Headspace solid-phase microextraction (SPME) with an $85 \mu \mathrm{m}$ Carboxen polydimethylsiloxane (CAR/PDMS) fiber was used to extract volatile compounds, and a gas chromatograph equipped with a mass spectometry detector (GCMS) was used to identify the volatile compounds in honeys. Thirty-four different volatile compounds from the headspace of honey produced in the central valley of Nuble Province, Chile, were extracted with fiber coating CAR/PDMS. The identified compounds were: 10 alcohols, 9 acids, 6 ketones, 3 aldehydes, 2 furans, 2 terpenes and 2 lactones. Only four of the volatile compounds had never been reported before as honey compounds; these being: 1,3-propanodiol, 2-methyl butanoic acid, 3,4-dimethyl-3-hexen-2-one, and 6-methyl-5-octen-2-one. These four compounds were found in three of the 10 analyzed samples. The compounds found in the highest percentage of area were ethanol, acetic acid, 1-hydroxy-2-propane, 3-hydroxy-2-butane, and furfural. However, the analyzed samples did not present a distinctive profile.
\end{abstract}

Key words: solid phase microextraction, volatile compounds, honey.

\section{INTRODUCTION}

Chile's internal demand for honey has increased significantly in recent years, while exports to the main markets of the US and Europe have expanded progressively. Under these circumstances, it is necessary to produce honey with unique properties that certify its origin. The productive sector has undoubtedly demonstrated a capacity for modernization and improvement of quality and productivity by adapting to increasing consumer demand.

Like any food product, honey has unique organoleptic and aromatic properties that determine consumer preference. Aroma is one of the most important features, since it also allows detection of adulteration of the product. Aroma in honey is attributed to different low-molecularweight chemical compounds. Some compounds, all of them volatile, are derived directly from the flowers visited by bees, therefore, the aroma has a floral origin. Others, however, are generated during honey processing and storage (Castro-Vázquez et al., 2007).

Because honey inherits plants properties, its color,

'Universidad del Bío-Bío, Facultad de Ciencias de la Salud y de los Alimentos, Av. Andrés Bello S/N, Casilla 447, Chillán, Chile. "Corresponding author (mgianel@ubiobio.cl).

Received: 12 November 2008.

Accepted: 28 April 2009. aroma, flavor, density, and physical and chemical properties depend on the flowers used by bees, although weather conditions also influence honey composition and properties (Ramírez and Montenegro, 2004).

Volatile compounds in honey originate from plant components through the direct generation of aromatic compounds by bees, as well as thermo-generation of aromatic compounds and the action of microorganisms (Serra and Ventura, 2003; Bastos and Alves, 2003; Iglesias et al., 2004; Castro-Vázquez et al., 2006a; Baroni et al., 2006).

The main volatile compounds in honey have their origins, in general terms, in different chemical families, such as: alcohols, ketones, aldehydes, acids, esters, terpenes (Zhou et al., 2002; Bastos and Alves, 2003).

Several techniques have been developed to identify and qualify volatile compounds that are responsible for aroma. In solid phase micro extraction (SPME) volatile compounds are adsorbed from the sample headspace. The compounds are adsorbed by a fiber in the SPME unit. Recent studies report that SPME is efficient for the extraction of volatile compounds in honey (Pérez et al., 2002; Alissandrakis et al., 2007; Jerkovic et al., 2009). However, the composition of volatile compounds depends on the extraction method (Alissandrakis et al., 2005). Not all compounds have an impact on honey aroma since the concentration of the volatile compound must exceed the perception threshold. However, a few compounds with 
low concentrations can still contribute significantly to honey aroma (Castro-Vázquez et al., 2007).

Specific volatile compounds can be considered as aroma fingerprints because they provide information about the botanic origin of the honey (Alissandrakis et al., 2005; Escriche et al., 2009). Several studies have been published on volatile compounds in honey (Pérez et al., 2002; Castro-Vázquez et al., 2006a; 2006b; Cuevas-Glory et al., 2007). Nevertheless, there are no studies about the fraction of volatile compounds in honey produced in Chile. The objective of this research was to study the volatile compounds of honey produced in the central valley of Nuble Province.

\section{MATERIALS AND METHODS}

\section{Sample}

Ten samples of honey from different apiculturists of the central valley of Ñuble Province were analyzed. The zone was divided into three sub-areas: eastern, central and western (Figure 1). The analyzed samples were from a harvest in 2007 and were stored at ambient temperature until analysis.

\section{Procedure}

A $4 \mathrm{~g}$ sample was placed in a $10 \mathrm{~mL}$ vial closed with a plastic twisted-off lid and sealed with PTFE silicone septum (Supelco, Bellefonte, Pennsylvania, USA) The sample was kept inside the vial at $30{ }^{\circ} \mathrm{C}$ in a thermo block

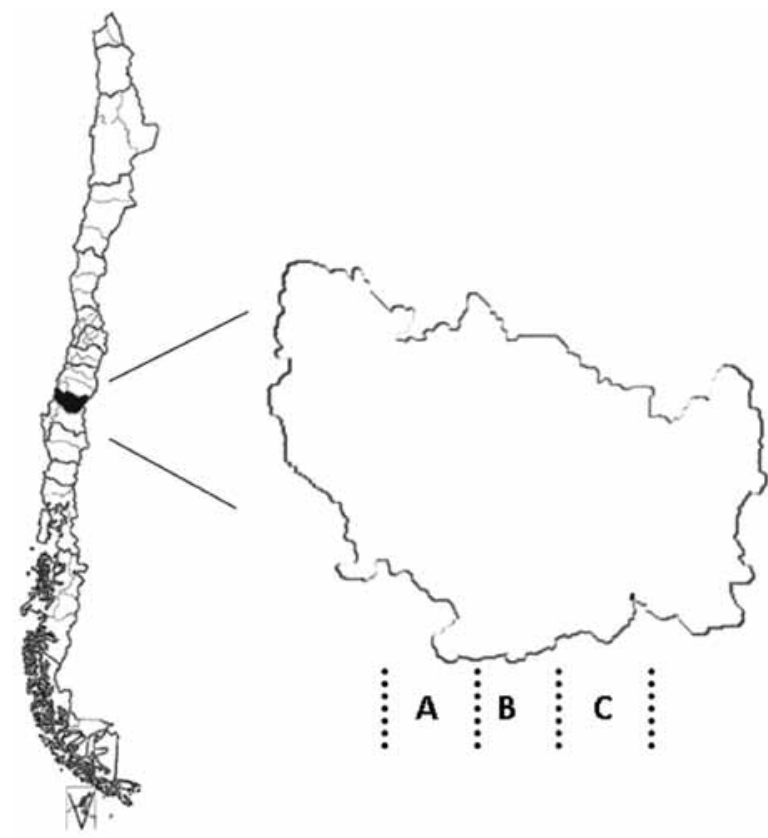

Figure 1. Sampled zones in Ñuble Province. (A) eastern; (B) central; (C) western.
(Equilab 2050-ICE, Paris, France) for $30 \mathrm{~min}$ to balance the headspace with the volatile compounds.

\section{Extraction of compounds}

After 30 min of balancing, the SPME fiber (Carboxen polydimethylsiloxane, CAR/PDMS $85 \mu \mathrm{m}$, SigmaAldrich, St. Louis, Missouri, USA) was exposed in the vial headspace for $1 \mathrm{~h}$ at $30^{\circ} \mathrm{C}$. Before analysis, fibers were preconditioned in the injection port as indicated by the manufacturer.

\section{Identification and quantification of volatile compounds}

The volatile compounds adsorbed by the fiber were desorbed in the injection port of the gas chromatograph Shimadzu GC, series GC-17-A, equipped with a massselective detector Shimadzu GCMS QP5050A (Kyoto, Japan). Desorption was performed by keeping the fiber in the injection port for $5 \mathrm{~min}$ at $220{ }^{\circ} \mathrm{C}$ with the purge valve off (splitless mode). The compounds were separated in a DB-624 capillary column $60 \mathrm{~m}$ long, $0.25 \mathrm{~mm}$ ID, with a film thickness of $1.8 \mu \mathrm{m}$ (J\&W Scientific, Folsom, California, USA). Helium was used as the carrier gas at a linear velocity of $39.7 \mathrm{~cm} \mathrm{~s}^{-1}$. The temperatures of the detector and injector were 240 and $220{ }^{\circ} \mathrm{C}$, respectively. The SPME fiber was manually injected and maintained in the injection port for $5 \mathrm{~min}$, at $220^{\circ} \mathrm{C}$, with the purge valve off (splitless mode). The temperature program began when the fiber was inserted, the temperature was maintained at $38{ }^{\circ} \mathrm{C}$ for $8 \mathrm{~min}$, then increased by $8{ }^{\circ} \mathrm{C}$ $\min ^{-1}$ until reaching $110^{\circ} \mathrm{C}$. Subsequently, a second linear gradient of $4{ }^{\circ} \mathrm{C} \mathrm{min}^{-1}$ was applied until reaching $220^{\circ} \mathrm{C}$. The temperature was then maintained at $220^{\circ} \mathrm{C}$ for 15.5 $\mathrm{min}$, for a total of $60 \mathrm{~min}$. The line of transference to the mass spectrophotometer was maintained at $240{ }^{\circ} \mathrm{C}$. Mass spectra were obtained by electron impact at $70 \mathrm{eV}$. Mass spectra data of volatile compounds were acquired in the range 25-400 amu.

Samples were randomly analyzed and results were expressed as means with standard deviation and percentage of area. Volatile compounds were identified through mass spectra as compared to library contents Nist 107 and Nist 21, and calculations were made to obtain the Kovats Index (KI) for each compound.

\section{RESULTS AND DISCUSSION}

Thirty-four volatile compounds were identified in this study of 10 samples of honey produced in different areas of the central valley of Nuble Province: 10 alcohols, 9 acids, 6 ketones, 3 aldehydes, 2 furans, 2 terpenes and 2 lactones (Figure 2). Only four of the volatile compounds had never been reported before as honey compounds, these being: 1,3-propanodiol, 2-methyl butanoic acid, 


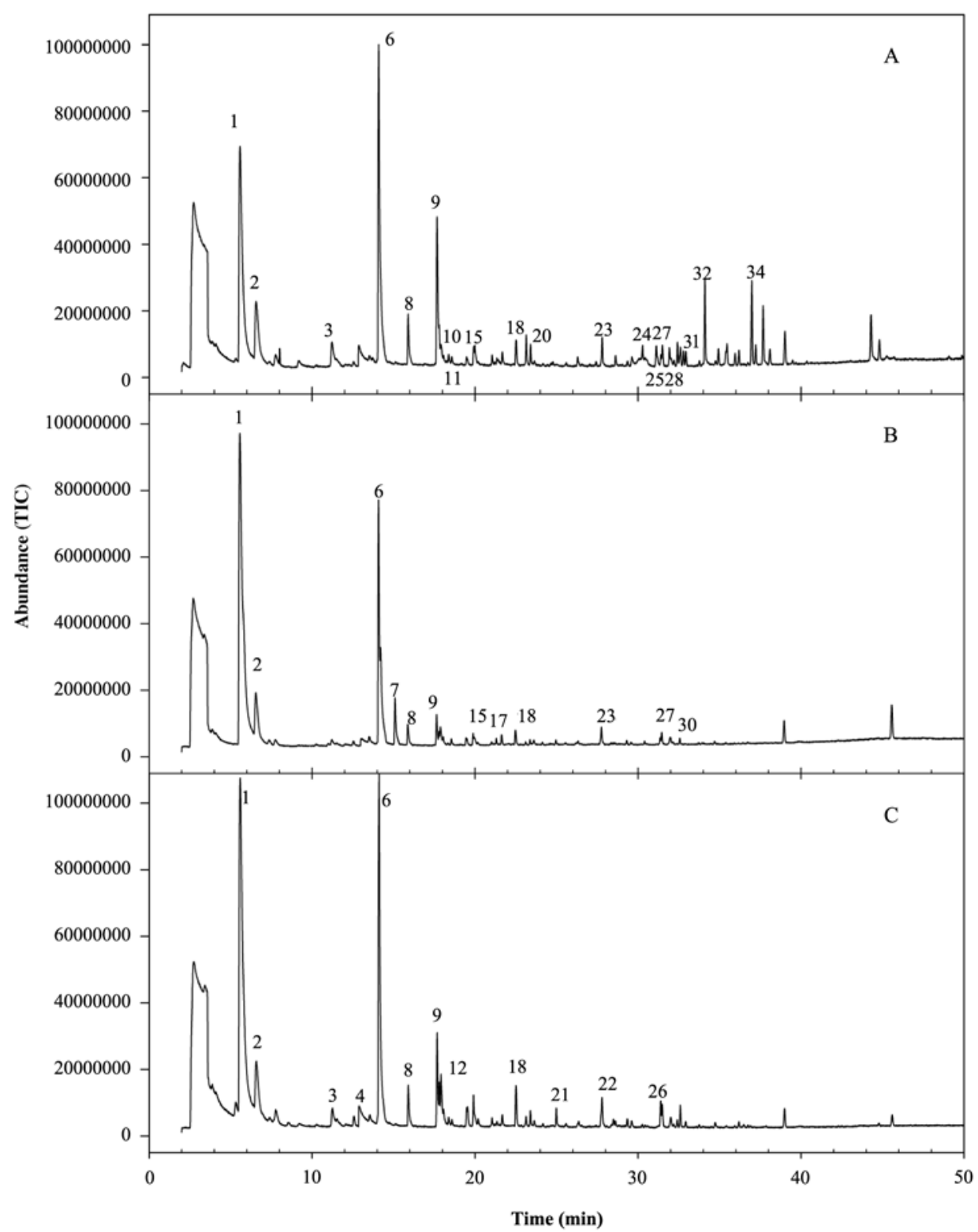

Figure 2. Chromatogram obtained by solid-phase microextraction gas-chromatography/mass spectrometry (SPME GC/ MS) after maintaining the SPME fiber (85 $\mu$ m Carboxen polydimethylsiloxane) for $1 \mathrm{~h}$ at $30{ }^{\circ} \mathrm{C}$ in the headspace honey. (A) eastern; (B) central; (C) western. The numbers represent compounds identified and listed in Tables 1, 2 and 3.

3,4-dimethyl-3-hexen-2-one, 6-methyl-5-octen-2-one. These four compounds were found in three of the 10 analyzed samples (Tables 1,2, and 3).

Formic acid is an organic compound found in nature. It appears in a diversity of organisms and is also one of the natural compounds of honey (Eguaras et al., 2003). Two enzymatic methods, high performance liquid chromatography (HPLC) and capillary zone electrophoresis (CZE) can be used to recognize this compound in honey (Suárez-Luque et al., 2006). Mato et al. (2006) conducted a study to determine non-aromatic acids in honey, in which they pointed out that organic acids such as gluconic acid, formic acid and lactic acids had higher concentrations in honey than acids of botanic origins. Formic acid was identified in only two of the samples from the central valley (Tables 1 and 3).

Compounds found in all samples were: ethanol, with an area percentage between 14.9-69.21\%, acetic acid with 


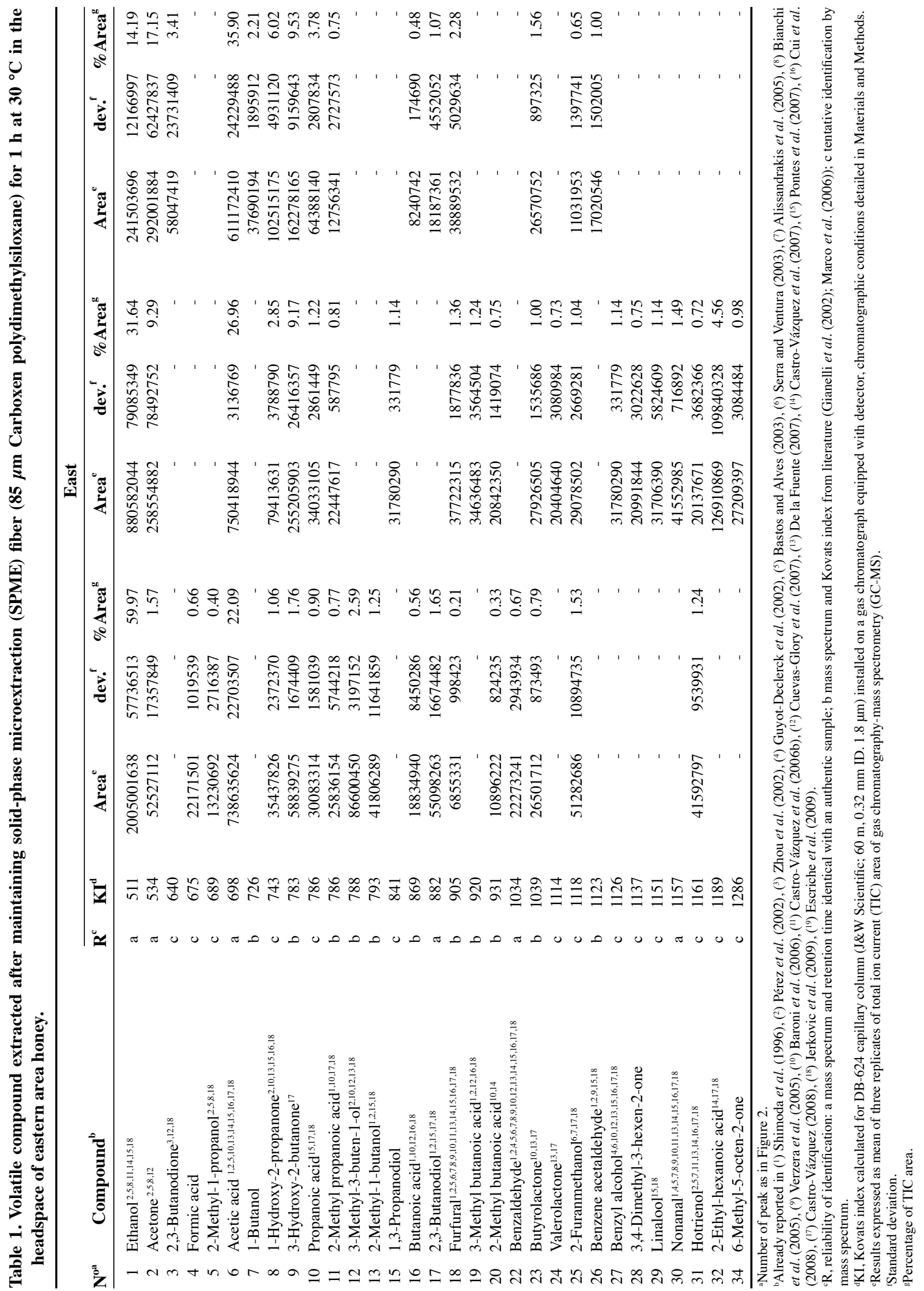




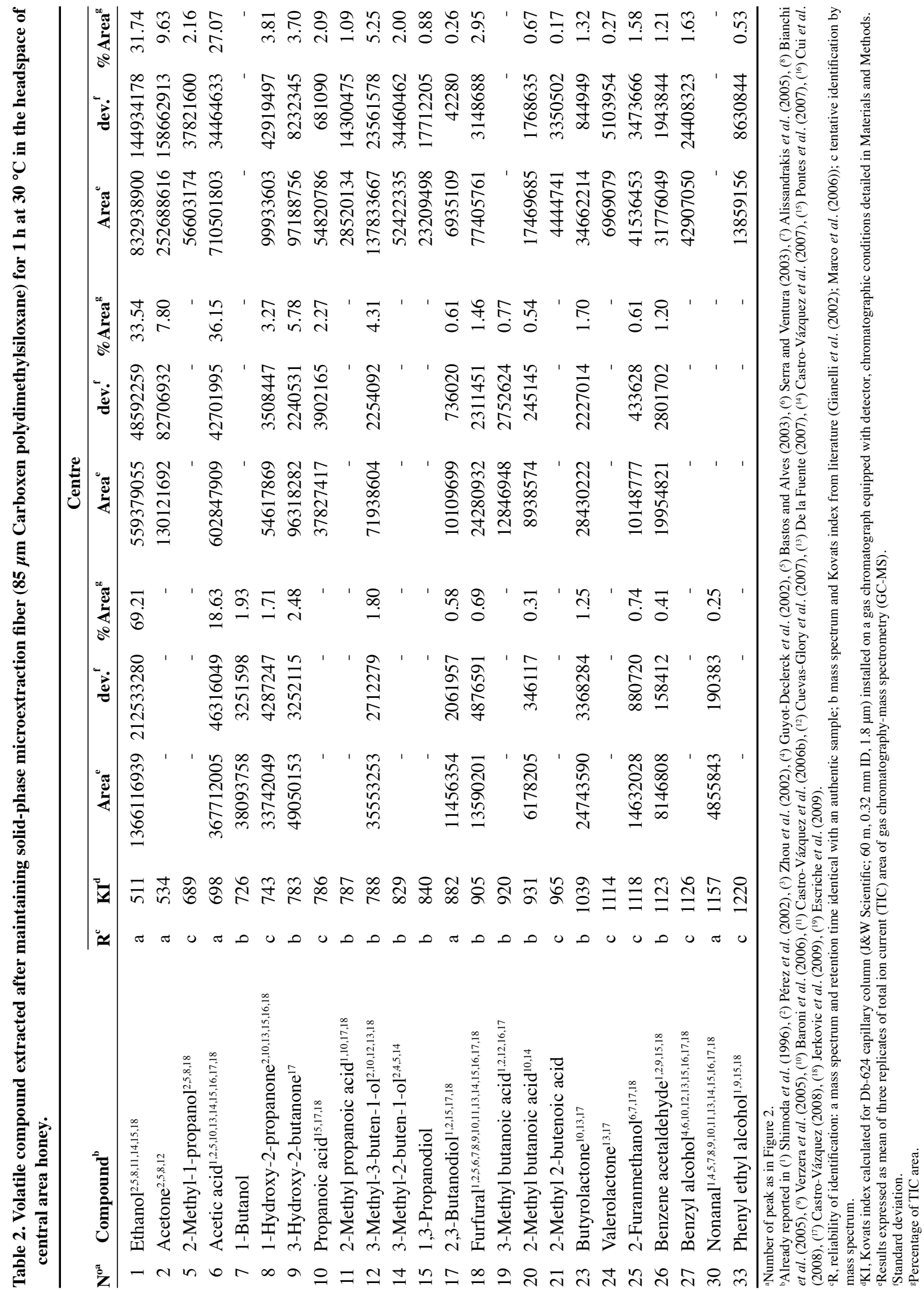


an area percentage between 17.32-36.15\%, 1-hydroxy-2propanone with an area percentage between 1.06-6.02\%, 3-hydroxy-2-butanone with an area percentage between $1.63-10.30 \%$ and furfural with an area percentage between $0.21-2.96 \%$ (Tables 1, 2, and 3).

Alcohols represent an important compound in honey; methyl alcohols, such as 3-methyl-3-buten-1-ol and 2-methyl-2-buten-1-ol have been described as adding a fresh flavor, their presence is associated with different floral origins (Castro-Vázquez et al., 2007). Ethanol, 2-methyl-propanol, and 3-methyl-3-buten-1-ol were described as very relevant compounds in lavender uniflorous honey (Cuevas-Glory et al., 2007). However, the presence of 3-methyl-3-buten-1-ol has also been associated with rosemary uniflorous honey (De la Fuente et al., 2005).

Among the identified alcohols, ethanol presented the highest response area percentage in all analyzed samples. Bastos and Alves (2003) suggest that the high content of ethanol and 2-methyl-propanol was due to the presence of yeast. However, ethanol and 2-methyl-propanol were described as inherent compounds to lavender honey (Cuevas-Glory et al., 2007). On the other hand, CAR/ PDMS fiber has high affinity with low-molecular-weight compounds, such as ethanol and acetic acid (Gianelli et al., 2002), which explains the large amount of all these compounds in all analyzed samples. It is important to keep in mind that the composition of volatile compounds depends on the extraction method (Alissandrakis et al., 2005).

Phenyl-ethyl alcohol is present in several types of honey (Shimoda et al., 1996; Serra and Ventura, 2003; Alissandrakis et al., 2005), however, this alcohol was identified in only one of the samples of the central valley, with an area percentage of $0.53 \%$ (Table 2).

Carboxylic acids are chemical compounds that have different aromas, ranging from spicy to rancid depending on the length of the carbonade chain. Short chain acids, like acetic acid, have spicy flavors and aromas, while butanoic acid and hexanoic acids in butter are linked to rancid aroma. On the other hand, Shimoda et al. (1996) pointed out that butanoic acid and 3-methyl butanoic acid give haze honey (Rhus succedanea $\mathrm{L}$.) its typical pungent smell. The hazel is a native tree from China, India, Taiwan, Japan, and Malaysia. Butanoic acid has been identified in two eastern area honey samples with an area percentage that ranged between $0.48 \%-0.56 \%$ and in one western area sample with an area percentage of $0.2 \%$. 3-methyl butanoic acid was found in one eastern area sample with a $1.24 \%$ area and in one central area with a $0.67 \%$ area.

Acetic and butyric acids might be produced in bee metabolism (Bastos and Alves, 2003). However, butyric acid was not identified in any of the 10 analyzed samples.
There is no certainty of the origin of 2-ethyl-hexanoicacid, although, this compound has been identified among the volatile compounds of wine and beer (De la Fuente $e t$ al., 2007).

Ketones, such as 3-hydroxy-2 butanone and acetone, are floral markers. 3-hydroxy-2 butanone has been identified as a distinctive feature of eucalyptus honey and is considered to be a floral marker for this type of honey (Pérez et al., 2002; Castro-Vázquez et al., 2006a; 2006b). It was also identified as a relevant compound of lime and rosemary uniflorous honey. On the other hand, acetone was identified as a relevant compound of acacia and rosemary uniflorous honey (Cuevas-Glory et al., 2007).

Acetone was found in the three eastern area samples, its area percentage ranged between $1.57-17.15 \%$. It was also found in two of the samples from the central area, with an area percentage between 7.8-9.63\% and in three western area samples with an area percentage between 5.00-13.13\% (Tables 1, 2, and 3).

Bastos and Alves (2003) pointed out that the acetone compound is typical of fir honey (Abies spp.), one of the most common introduced tree species in Chile.

Aldehydes identified in the analyzed samples were: benzaldehyde, benzalacetaldehyde and nonanal. Benzaldehyde was found in an eastern area sample, with an area percentage of $0.67 \%$ and in one western area sample, with an area percentage of $0.80 \%$. Some derived benzene, such as benzaldehyde, benzyl alcohol and 2-phenylethanol have been reported in most European and Australian honey, with a variety of floral origins. Benzaldehyde has also been identified as a relevant compound of lavender, acacia and rosemary honey (Soria et al., 2003; Cuevas-Glory et al., 2007).

Volatile compounds benzaldehyde and benzene acetaldehyde have been reported as common aromatic compounds in honey samples (Shimoda et al., 1996; Serra and Ventura, 2003; Alissandrakis et al., 2005; Baroni et al., 2006; Castro-Vázquez et al., 2006a).

Benzene acetaldehyde was identified in all of the central and western area samples, their area percentage ranged between $0.41-1.21 \%$ and $0.30-1.66 \%$, respectively. It was also identified in one eastern area sample with an area percentage of $1.00 \%$ (Tables 1, 2, and 3). Benzene acetaldehyde is considered one of the compounds that gives honey its characteristic honey aroma (CastroVázquez et al., 2007). This compound is also relevant in lavender uniflorous honey (Cuevas-Glory et al., 2007).

Benzaldehyde, benzene acetaldehyde, and 2-phenylethanol have been isolated by using different extraction methods and form parts of the aromas of different types of honey (Alissandrakis et al., 2005). Some compounds derived from benzene, such as: benzaldehyde, benzyl alcohol, and phenyl ethyl alcohol, were reported 


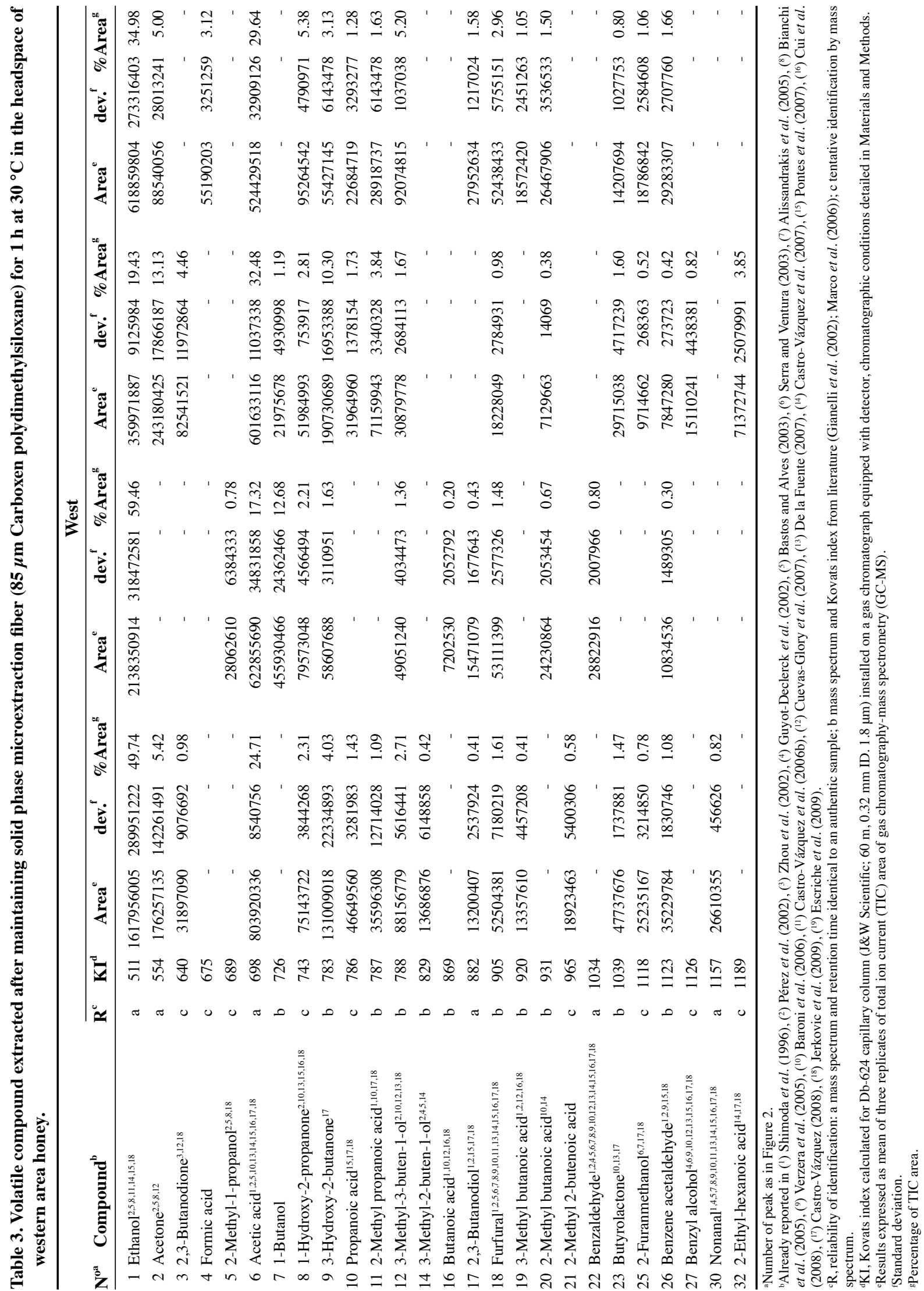


to be present in most European and Australian honey and in a wide variety of floral origins (Castro-Vázquez et al., 2007).

Nonanal was identified in one sample per each sample areas, with an area percentage of $1.49 \%$ in the eastern area, $0.25 \%$ in the central, and $0.82 \%$ in the western (Tables 1 , 2 , and 3). Nonanal was also extracted by using SPME and is a relevant volatile compound in eucalyptus uniflorous honey (Cuevas-Glory et al., 2007). This compound presented a floral aroma (Ponce, 2006).

On the other hand, enzymes from the reductasa group, whose origin is the bee organism, may convert benzene acetaldehyde into benzyl alcohol (Bastos and Alves, 2003). Benzaldehyde in particular has been described as a characteristic aromatic compound of chestnut honey (Serra and Ventura, 2003).

Furan derived compounds identified in the honey samples were: furfural and 2-furanmethanol. Furfural was present in all samples, but 2-furanmethanol was identified in nine of the analyzed samples, only in one western area sample it did not show up. The 2-furanmethanol area percentage ranged between $0.65-1.53 \%$ in the eastern area, between $0.61-1.58 \%$ in the central and between $0.52-1.06 \%$ in the western area (Tables 1, 2, and 3). Compounds resulting from sugar degradation, such as: furfural, furfuryl alcohol and 5-methyl-furfural, derived from furan, were found in fresh citric honey. These compounds increased with storage and the increase was greater when temperature was raised from 10 to $40{ }^{\circ} \mathrm{C}$ (Castro-Vázquez et al., 2008). Compounds derived from furan are considered to be indicators of thermic processes and storage. They are not considered appropriate floral markers because they lose freshness with long periods of storage or exposure to high temperatures. In this study, 5-methyl-furfural was not identified among the compounds used to indicate deterioration (CastroVázquez et al., 2007). On the other hand, furfural was identified as a relevant compound of lime, lavender and acacia uniflorous honey, and 2-furanmethanol (furfuryl alcohol) was identified as a relevant compound in lavender uniflorous honey (Cuevas-Glory et al., 2007).

Furanic compounds are commonly generated by storage and heating (Sancho et al., 1992). The mild heating experienced by samples during SPME sampling, which is recommended in order to improve the extraction yield and to reduce the equilibrium time, could be partially responsible for some of these compounds (Soria et al., 2003).

Two samples from the eastern area showed the presence of 3,7-dimethyl-1,5,7-octatrien-3-ol (hotrienol) with a participation percentage that ranged between 0.72 $1.24 \%$, which adds floral and fruity qualities to honey aroma (Zhou et al., 2002). Hotrienol has been found in citric honey and in a variety of honeys of different origins, especially lavender honey (Castro-Vázquez et al., 2007; Cuevas-Glory et al., 2007). This compound has also been reported as typical to citric honey, where it can be found in a high proportion. The same compound has also been reported as a component of several varieties of honey and essential oil of a significant number of plants; however, hotrienol could be produced thermically. Hotrienol aroma has been described as sweet and floral (Alissandrakis et al., 2003; 2007).

The main terpene found in Eucryphia lucida honey is 2,6-dimethyl-3,7-octadien-2,6-diol, which originates from floral nectar. Part of this diol is thermically dehydrated inside the beehive or during the process of forming hotrienol (3,7-dimethyl-1,5,7-octatrien-3-ol), an important aromatic compound detected in the analysis of the headspace of this type of honey (Alissandrakis et al., 2007). Hotrienol was also reported in citric honeys, such as orange honey and lavender honey (Verzera et al., 2005; Cuevas-Glory et al., 2007). This type of compound adds floral and fruity aroma (Zhou et al., 2002). The Eucryphia is a small botanic genus of native trees and large bushes in the temperate regions of South America and eastcoast Australian. Studies carried out in Chile have found this native uniflorous honey derived from Eucryphia cordifolia (ulmo tree) (Montenegro et al., 2008).

Spanish citric honey extracts are rich in terpenes and its derivations (Castro-Vázquez et al., 2007). Linalool was detected in only one eastern area sample, with an area percentage of $1.14 \%$ (Table 1). This compound was predominant in citric flowers, and it is considered that $80 \%$ of the compounds of citric honey extracts derive from linalool. Thus, the distinctive feature of citric honey is the presence of linalool and its derivations (Alissandrakis et al., 2003).

Cyclic esters that make a major sensorial contribution are known as lactones, butirolactone being an example (Castro-Vázquez et al., 2006a). This compound was not found in fresh citric honey extracts. However, the concentration of these compounds gradually increases with higher temperature (Castro-Vázquez et al., 2008).

Some organic acids, ketones and benzenes, such as 2-hydroxy-2-propanone, butanoic acid, benzil alcohol or 2-phenyl-ethanol found in fresh honey gradually increase their concentration with higher temperature and storage (Castro-Vázquez et al., 2008).

\section{CONCLUSION}

Volatile compounds identified in honeys from Nuble Province have been reported before in other honey studies. Variations in volatile composition among analyzed honeys are shown. However, all samples present a majority of 
the same chemical groups. Further studies are necessary to characterize the aroma and floral origins of honeys in Ñuble Province.

\section{ACKNOWLEDGEMENTS}

This work has been supported by grant 045821 4/RS, Universidad del Bío-Bío, Chile.

\section{RESUMEN}

Compuestos volátiles en miel producida en el Valle Central de la Provincia de Nuble, Chile. La extracción de compuestos volátiles desde el espacio de cabeza de mieles se realiza mediante microextracción en fase sólida (SPME), utilizando una fibra de $85 \mu \mathrm{m}$ de Carboxen polidimetilsiloxano (CAR/PDMS), el análisis de los compuestos volátiles se realiza mediante cromatografía de gases con detector de masa (GC-MS). Un total de 34 diferentes compuestos volátiles fueron extraídos desde el espacio de cabeza de mieles provenientes del valle central de la provincia de Nuble con la fibra de CAR/PDMS. Los compuestos identificados fueron 10 alcoholes, 9 ácidos, 6 cetonas, 3 aldehídos, 2 furanos, 2 terpenos y 2 lactonas. De los compuestos volátiles sólo tres no han sido reportados con anterioridad en mieles, estos compuestos fueron: 1,3-propanodiol, ácido 2-metil butanoico, 3,4-dimetil3-hexen-2-ona, 6-metil-5-octen-2-ona. Estos cuatro compuestos se encontraron en sólo tres de las 10 muestras analizadas. Los compuestos que se encontraron en un mayor porcentaje de área fueron etanol, acido acético, 1-hidroxi-2-propano, 3-hidroxi-2-butano y furfural; sin embargo, las muestras analizadas no presentan un perfil aromático característico.

Palabras clave: microextracción de fase sólida, compuestos volátiles, miel.

\section{LITERATURE CITED}

Alissandrakis, E., D. Daferera, P. Tarantilis, M. Polissiou, and P.C. Harizanis. 2003. Ultrasound-assisted extraction of volatile compounds from citrus flowers and citrus honey. Food Chem. 82:575-582.

Alissandrakis, E., P. Tarantilis, P. Harizanis, and M. Polissiou. 2005. Evaluation of four isolation techniques for honey aroma compounds. J. Sci. Food Agric. 85:91-97.

Alissandrakis, E., P. Tarantilis, P. Harizanis, and M. Polissiou. 2007. Aroma investigation of unifloral Greek citrus honey using solid-phase microextraction coupled to gas chromatographic-mass spectrometric analysis. Food Chem. 100:396-404.
Baroni, M.V., M.L. Nores, M Díaz, G.A. Chiabrando, J.P. Fassano, C. Costa, and D. Wunderlin. 2006. Determination of volatile organic compound patterns characteristic of five unifloral honey by solidphase microextraction-gas chromatography-mass spectrometry coupled to chemometrics. J. Agric. Food Chem. 54:7235-7241.

Bastos, C., and R. Alves. 2003. Compostos voláteis em méis florais. Quim. Nova 26:90-96.

Bianchi, F., M. Careri, and M. Musci. 2005. Volatile norisoprenoides as markers of botanical origin of Sardinian strawberry- tree (Arbutus unedo L.) honey: Characterisation of aroma compounds by dynamic headspace extraction and gas chromatography-mass spectrometry. Food Chem. 89:527-532.

Castro-Vázquez, L., M.C. Díaz-Maroto, E. Guchu, and M.S. Pérez-Coello. 2006b. Analysis of volatile compounds of Eucalyptus honey by solid phase extraction followed by gas chromatography coupled to mass spectrometry. Eur. Food Res. Technol. 224:2731.

Castro-Vázquez, L., M.C. Díaz-Maroto, and M.S. PérezCoello. 2006a. Volatile composition and contribution to the aroma of Spanish honeydew honeys. Identification of a new chemical marker. J. Agric. Food Chem. 54:4809-4813.

Castro-Vázquez, L., M.C. Díaz-Maroto, and M.S. PérezCoello. 2007. Aroma composition and new chemical markers of Spanish citrus honeys. Food Chem. 103:601-606.

Castro-Vázquez, L., M.C. Díaz-Maroto, M.A. GonzálezViñas, E. De La Fuente, and M.S. Pérez-Coello. 2008. Influence of storage conditions on chemical composition and sensory properties of citrus honey. J. Agric. Food Chem. 56:1999-2006.

Cuevas-Glory, L., J. Pino, L. Santiago, and E. SauriDuch. 2007. A review of volatile analytical methods for determining the botanical origin of honey. J. Food Chem. 103:1032-1043.

Cui, Z.W., L.J. Sun, W. Chen, and D.W. Sun. 2008. Preparation of dry honey by microwave-vacuum drying. J. Food Eng. 84:582-590.

De la Fuente, E., I. Martínez-Castro, and J. Sanz. 2005. Characterization of Spanish unifloral honeys by solid phase microextraction and gas chromatography-mass spectrometry. J. Sep. Sci. 28:1093-1100.

De la Fuente, E., M.L. Sanz, I. Martínez-Castro, J. Sanz, and A.I. Ruiz-Matute. 2007. Volatile and carbohydrate composition of rare unifloral honeys from Spain. Food Chem. 105:84-93. 
Eguaras, M., M.A. Palacio, C. Faverin, M. Basualdo, M.L. Del Hoyo, G. Velis, and E. Bedascarrasbure. 2003. Efficacy of formic acid in gel for Varroa control in Apis mellifera $\mathrm{L}$.: Importance of the dispenser inside the hive. Vet. Parasitol. 111:241-245.

Escriche, I., M. Visquert, M. Juan-Borras, and P. Fito. 2009. Influence of simulated industrial thermal treatments on the volatile fractions of different varieties of honey. Food Chem. 112:329-338.

Gianelli, M.P., M. Flores, and F. Toldrá. 2002.Optimisation of solid phase microextraction (SPME) for the analysis of volatile compounds in dry-cured ham. J. Sci. Food Agric. 82:1703-1709.

Guyot-Declerck, C., S. Renson, A. Bouseta, and S. Collin. 2002. Floral quality and discrimination of Lavandula stoechas, Lavandula angustifolia, and Lavandula angustifolia x latifolia. Food Chem. 79:453-459.

Iglesias, M.T., C. De Lorenzo, M. Polo, P.J. MartínAlvares, and E. Pueyo. 2004. Usefulness of amino acid composition to discriminate between honeydew and floral honeys. Application to honeys from a small geographic area. J. Agric. Food Chem. 52:84-89.

Jerkovic, J., C.U.G. Tuberoso, Z. Marijanovic, M. Jelic, and A. Kasum. 2009. Headspace volatile and semivolatile patterns of Paliurus spina-christi unifloral honey as markers of botanical origin. Food Chem. 112:239-245

Marco, A., J.L. Navarro, and M. Flores. 2006. The influence of nitrite and nitrate on microbial, chemical and sensory parameters of slow dry fermented sausage. Meat Sci. 73:600-673.

Mato, I., J.F. Huidrobro, J. Simal-Lozano, and M.T. Sancho. 2006. Rapid determination of nonaromatic organic acids in honey by capillary zone electrophoresis with direct ultraviolet detection. J. Agric. Food Chem. 54:1541-1550.

Montenegro, G., M. Gómez, J. Díaz Forestier, and R. Pizarro. 2008. Aplicación de la Norma Chilena Oficial de denominación de origen botánico de la miel para la caracterización de la producción apícola. Cien. Inv. Agr. 35:181-190.

Pérez, R., C. Sánchez-Brunete, R.M. Calvo, and J.L. Tadeo. 2002. Analysis of volatiles from Spanish honeys by solid-phase microextraction and gas chromatography-mass spectrometry. J. Agric. Food Chem. 50:2633-2637.
Ponce, E. 2006. Aroma y sabor. p. 473-492. In Baudi, S. (ed.) Química de los alimentos. Person Educación, México.

Pontes, M., J.C. Marques, and J.S. Camara. 2007. Screening of volatile composition from Portuguese multifloral honeys using headspace solid-phase microextraction-gas chromatography-quadrupole mass spectrometry. Talanta 74:91-103.

Ramírez, R., y G. Montenegro. 2004. Certificación del origen botánico y polen corbicular perteneciente a la comuna de Litueche, VI Región de Chile. Cien. Inv. Agr. 31:197-211

Sancho, M.T., S. Muniagui, J.F. Huidrobo, and S. Lozano. 1992. Aging of honey. J. Agric. Food Chem. 40:134136.

Serra, J., and F. Ventura. 2003. Flavour index and aroma profiles of fresh and processed honeys. J. Sci. Food Agric. 83:275-282.

Shimoda, M., Y. Wu, and Y. Osajima. 1996. Aroma compounds from aqueous solution of Haze (Rhus succedanea) honey determined by adsorptive column chromatography. J. Agric. Chem. 44:3913-3918.

Soria, A.C., I. Martínez-Castro, and J. Sanz. 2003. Analysis of volatile composition of honey by solid phase microextraction and gas chromatography-mass spectrometry. J. Sep. Sci. 26:793-801.

Suárez,-Luque, S., I. Mato, J.F. Huidobro, J. SimalLozano, and M.T Sancho. 2006. Capillary zone electrophoresis method for the determination of inorganic anions and formic acid in honey. J. Agric. Food Chem. 54:9292-9296.

Verzera, A., S. Campisi, M. Zappala, W. Gmelin, and I. Bonaccorsi. 2005. Using SPME-GC-MS to characterize volatile components in honey as indicators of botanical origin. The Reporter (Europe), International Issue 16:9-12.

Zhou, Q., C.L. Wintersteen, and K.R. Cadwallader. 2002. Identification and quantification of aroma-active components that contribute to the distinct malty flavor of buckwheat honey. J. Agric. Food Chem. 50:20162021. 